Nutrition is one of the key factors that modulate exercise performance. In this book, a group of expert scientists discuss the ergogenic properties of various nutritional interventions and present research to show that dietary strategies can be applied to extend the limits of human endurance, lower the risk of illness or injury, and speed recovery rates. More specifically, they discuss recent findings on topics such as caffeine and its effect on the brain, carnitine and fat oxidation, ergogenic properties of beta-alanine, dietary protein and muscle reconditioning, nutrition and immune status, and the importance of proper hydration.

This publication will provide the reader with many novel insights into the complex interaction between nutrition and exercise, allowing them to define more effective dietary strategies to improve health and performance. Moreover, while focusing on elite athletes, it is interesting to note that some of the discoveries can be applied beyond this niche, for example to improve performance outcomes in the elderly.

Nestlé Nutrition Institute Series, Vol. 76

Limits of Human Endurance

Editors: van Loon, L.J.C. (Maastricht); Meeusen, R. (Brussels)

XIV + 130 p., 17 fig., 9 tab., 2013

CHF 50.- / EUR 42.- / USD 59.00 (hard cover)

CHF 60.- / EUR 50.- / USD 71.00 (online)

Online versions for institutional purchase

Prices subject to change

EUR price for Germany, USD price for USA only

ISBN 978-3-318-02408-1 (hard cover)

e-ISBN 978-3-318-02409-8

Fields of Interest: Nutrition; Sports Medicine; Clinical Nutrition
How to improve exercise performance capacity through adequate nutrition

Nestlé Nutrition Institute Workshop Series, Vol. 76

\section{Limits of Human Endurance}

Editors

\section{Luc J.C. van Loon \\ Romain Meeusen}

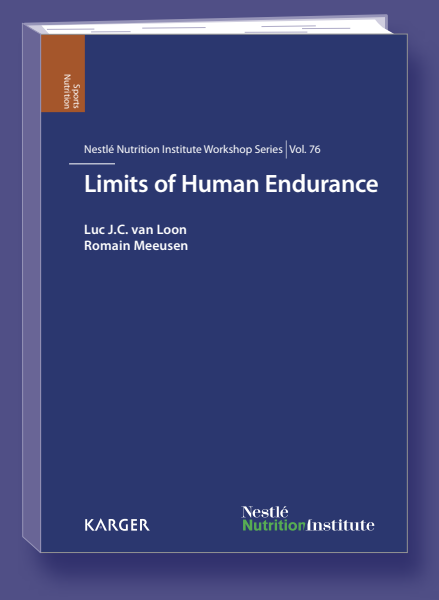

\section{Contents}

Preface

Foreword

Contributors

Caffeine, Exercise and the Brain: Meeusen, $R$.; Roelands, B.; Spriet, L.L.

Carnitine and Fat Oxidation: Stephens, F.B.; Galloway, S.D.R.

Hydration during Intense Exercise Training: Maughan, R.J.; Meyer, N.L.

Intense Exercise Training and Immune Function: Gleeson, M.; Williams, $C$.

Physiological and Performance Adaptations to High-Intensity Interval Training: Gibala, M.J.; Jones, A.M.
Effect of $\beta$-Alanine Supplementation on High-Intensity Exercise Performance: Harris, R.C.; Stellingwerff, T.

Dietary Protein for Muscle Hypertrophy: Tipton, K.D.; Phillips, S.M.

The Role of Amino Acids in Skeletal Muscle Adaptation to Exercise:

Aguirre, N.; van Loon, L.J.C.; Baar, K.

National Nutritional Programs for the 2012 London Olympic Games: A Systematic Approach by Three Different Countries: Burke, L.M.;

Concluding Remarks: Nutritional Strategies to Increase Performance Capacity: van Loon, L.J.C.; Meeusen, $R$. Meyer, N.L.: Pearce, J. 


\section{Order Form}

\section{Nestlé Nutrition Institute Workshop Series}

\section{ISSN 1664-2147}

e-ISSN 1664-2155

In 2011, the two book series 'Nestlé Nutrition Workshop Series: Pediatric Program' and 'Nestlé Nutrition Workshop Series: Clinical \& Performance Program' have been merged to form the 'Nestlé Nutrition Institute Workshop Series'. One of the major components of this series is the organization of workshops and the publication of the proceedings. Each workshop focuses on the latest findings, the controversies and further research needs concerning various topics in nutrition.

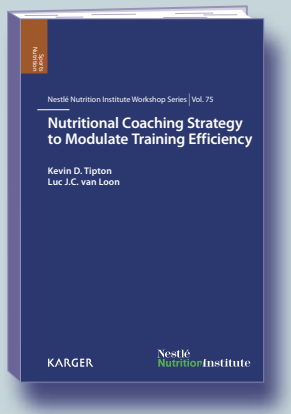

Vol. 75

Nutritional Coaching Strategy to Modulate Training Efficiency

Editors: Tipton, K.D. (Stirling); van Loon, L.J.C. (Maastricht)

XIV + 146 p., 16 fig., 13 tab., hard cover, 2013

CHF 50.- / EUR 42.- / USD 59.00 (hard cover)

CHF 60.- / EUR 50.- / USD 71.00 (online)

ISBN 978-3-318-02332-9 (hard cover)

e-ISBN 978-3-318-02333-6
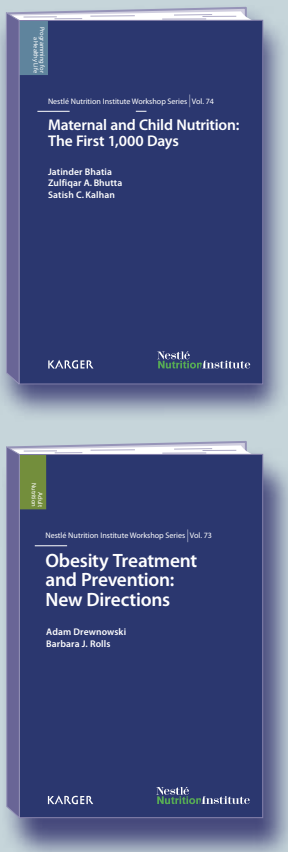

Vol. 74

Maternal and Child Nutrition: The First 1,000 Days

Editors: Bhatia, J. (Augusta, Ga.); Bhutta, Z.A. (Karachi);

Kalhan, S.C. (Cleveland, Ohio)

XVIII + 238 p., 31 fig., 10 tab., hard cover, 2013

CHF 50.- / EUR 42.- / USD 59.00 (hard cover)

CHF 60.- / EUR 50.- / USD 71.00 (online)

ISBN 978-3-318-02387-9 (hard cover)

e-ISBN 978-3-318-02388-6

Vol. 73

Obesity Treatment and Prevention: New Directions

Editors: Drewnowski, A. (Seattle, Wash.);

Rolls, B.J. (University Park, Pa.)

XVI + 150 p., 12 fig., 8 tab., hard cover, 2012

CHF 50.- / EUR 42.- / USD 59.00 (hard cover)

CHF 60.- / EUR 50.- / USD 71.00 (online)

ISBN 978-3-318-02115-8 (hard cover)

e-ISBN 978-3-318-02116-5

Online versions are for institutional purchase

Prices subject to change

EUR price for Germany, USD price for USA only
Nestlé Nutrition Institute Workshop Series

\section{Please send}

copy/ies: Vol. 76: Limits of Human Endurance CHF 50.- / EUR 42.- / USD 59.00

ISBN 978-3-318-02408-1

_ copy/ies

ISBN 978-3-318-

The book series Nestlé Nutrition Institute Workshop Series on

continuation beginning with vol.

All Karger series are available on continuation. Each new volume will be sent upon publication until order is countermanded.

Postage and handling free with prepayment

For easy ordering or information

about other Karger publications log on to:

www.karger.com

Payment

$\bigcirc$ Check enclosed $\bigcirc$ Please bill me

$\bigcirc$ Please charge to my credit card

$\bigcirc$ American Express $\bigcirc$ Diners

$\bigcirc$ MasterCard $\bigcirc$ visa

Card No.

Exp. date:

CVV/CVC:

Name/Address:

Date:

Signature:

Orders can be placed at agencies, bookstores, directly

with the publisher, or with any Karger distributor.

S. Karger AG, P.O. Box, 4009 Basel (Switzerland)

Fax +41 6130612 34, E-Mail orders@ @arger.com

USA: S. Karger Publishers, Inc., 26 West Avon Road,

P.O. Box 529, Unionville, CT 06085 (USA),

Toll free: +1-800-828-5479

Germany: S. Karger GmbH, 79095 Freiburg

France: Librairie Médi-Sciences, 75007 Paris

Japan: Karger Japan, Inc., Tokyo 105-0012

South East Asia, China and Taiwan:

Karger Regional Office, Kuala Lumpur 50470 (Malaysia)

For details and further representatives

and agencies see www.karger.com/worldwide www.karger.com/nniws

\section{KARGER}

To be ordered through: 